\title{
ATHLETE'S ROLE IDENTITY: AN INTEGRATIVE REVIEW OF MEASUREMENT INSTRUMENTS
}

IDENTIDADEDO PAPEL DE ATLETA: UMA REVISÃO INTEGRATIVA DOS INSTRUMENTOS DE MEDIDA

IDENTIDAD DEL PAPEL DE ATLETA: UNA REVISIÓN INTEGRATIVA DE LOS INSTRUMENTOS DEMEDICIÓN

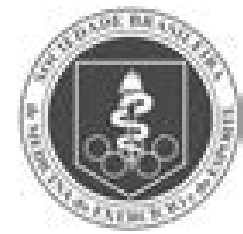

Review Article

ARTIGO DE REVISÃo ARtículo de REVISIÓN

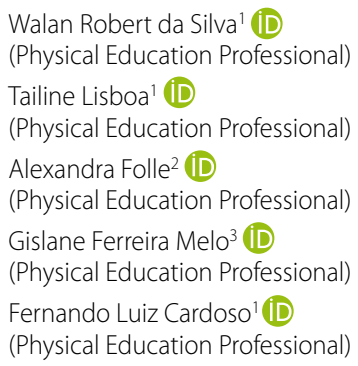

1. Universidade do Estado de Santa Catarina (UDESC), Centro de Ciências da Saúde e do Esporte (CEFID), Human Movement Science Graduate Studies Program (PPGCMH), Laboratório de Gênero, Educação, Sexualidade e Corporeidade (LAGESC), Florianópolis, SC, Brazil. 2. Universidade do Estado de Santa Catarina (UDESC), Centro de Ciências da Saúde e do Esporte (CEFID), Human Movement Science Graduate Studies Program (PPGCMH), Florianópolis, SC, Brazil. 3. Universidade Católica de Brasília (UCB), Brasília, Distrito Federal, Brazil.

\section{Correspondence:}

Rua Pascoal Simone, 358

Coqueiros, Florianópolis, SC, Brazil. CEP: 88080-350

walanrobert@hotmail.com

\begin{abstract}
Introduction: The identity of the role of athlete (athletic identity-Al) can be understood as an aspect of self-concept, more specifically as a cognitive structure that guides and organizes the processing of self-related information. Objective: To verify studies that have developed or validated instruments to measure Al, and to identify the psychometric properties presented by these instruments. Methods: We searched for articles in the Scopus, APA (PsycNET), Lilacs, Scielo, ScienceDirect, SPORTdiscus and Pubmed databases with the descriptors ("athletic identity" OR"social identity" OR "selfidentity"OR"athlete identity") AND ("athlete"OR"sport"OR"type of sport") AND ("validation"OR"validity"OR"adaptation"). Results: Of the 21 studies selected for analysis, the majority was found to have employed the theoretical assumption of athletic identity of Brewer, Van Raalte \& Linder (1993), while with regard to the validity process, it was ascertained that all the studies included in the review had construct validity. Conclusion: It is suggested that future studies into validation processes of instruments related to the identity of the role of athlete apply the Item Response Theory (IRT) to make the construct validation process more reliable, attaching greater importance to the items included in the instrument. In addition, it is recommended that the criterion validity process be carried out with the intention of verifying construct stability in different populations. Level of evidence II, Diagnostic studies - Investigating a diagnostic test.
\end{abstract}

Keywords: Social identification; Sports; Role; Professional role.

\section{RESUMO}

Introdução: Aidentidade do papel de atleta (identidade atlética - IA) pode ser entendida como um aspecto de autoconceito, mais especificamente como uma estrutura cognitiva que orienta e organiza o processamento das informações autorrelacionadas. Objetivo: Verificar os estudos que desenvolveram ou validaram os instrumentos para mensurar a IA e identificar as propriedades psicométricas apresentadas por esses instrumentos. Métodos: Buscaram-se artigos nas bases de dados Scopus, APA (PsycNET), Lilacs, Scielo, ScienceDirect, SPORTdiscus e Pubmed com os descritores ("athletic identity" OR "social identity" OR "self-identity" OR "athlete identity") AND ("athlete" OR "sport" OR "type of sport") AND ("validation" OR "validity" OR adaptation"). Resultados: Dos 21 estudos selecionados para análise, constatou-se que a maioria partiu do pressuposto teórico de identidade atlética de Brewer, Van Raalte \& Linder (1993), já quanto ao processo de validade, verificou-se que todos os estudos inseridos na revisão realizaram validade de construto. Conclusão: Sugere-se paraestudos futuros em processos de validação de instrumentos relacionados à identidade do papel de atleta que apliquem a Teoria de Resposta ao Item (TRI), a fim de deixar mais fidedigno o processo de validação de construto, dan do maior importância aos itens inseridos ao instrumento. Ainda, recomenda-se a realização do processo de validade de critério com intuito de verificar uma estabilidade do construto em diferentes populações. Nível de evidência ll, Estudos diagnósticos - Investigação de um exame para diagnóstico.

Descritores: Identificação social; Esportes; Papel; Papel profissional.

\section{RESUMEN}

Introducción: La identidad del papel de atleta (identidad atlética - IA) puede ser entendida como un aspecto de autoconcepto, más especificamente como una estructura cognitiva que orienta y organiza el procesamiento de las informaciones autorrelacionadas. Objetivo: Verificar los estudios que desarrollaron o validaron los instrumentos para medir l I IA e identificar las propiedades psicométricas presentadas por esos instrumentos. Métodos: Se buscaron artículos en las bases de datos Scopus, APA (PsyCNET), Lilacs, Scielo, ScienceDirect, SPORTdiscus y Pubmed con los descriptores ("athletic identity" OR "social identity" OR "self-identity" OR "athlete identity") AND ("athlete" OR "sport" OR "type of sport") AND ("validation" OR "validity" OR adaptation"). Resultados: De los 21 estudios seleccionados para análisis, se constató que la mayoría partió de la presunción teórica de identidad atlética de Brewer, Van Raalte y Linder (1993), ya cuanto al proceso de validez, se verificó que todos los estudios incluidos en la revisión realizaron validez de constructo. Conclusión: Se sugiere para futuros estudios en procesos de validación de instrumentos relacionados a la identidad del papel de atleta que apliquen la Teoría de Respuesta al Item (TRI) a fin de dejar más fidedigno el proceso de validación de constructo, dando mayor importancia a los ítems incluidos al instrumento. Además, se recomienda la realización del proceso de validez de criterio con el objetivo de verificar una estabilidad del constructo en diferentes poblaciones. Nivel de evidencia ll, Estudios diagnósticos - Investigación de un examen para diagnóstico.

Descriptores: Identificación social; Deportes; Rol; Rol profesional. 


\section{INTRODUCTION}

Self and identity are core concepts in Social and Behavioral Sciences. ${ }^{1}$ The earliest findings on these concepts can be attributed to James, ${ }^{2}$ who regarded the self as a prime determinant of human thoughts, actions, and feelings. Over the years incongruities in the identity theory have been highlighted: unity versus multiplicity, and personal versus social. ${ }^{3}$ In this context, identity studies have followed two traditions: the study of the identity formation process within psychological development, and the study of self in social psychology. ${ }^{4}$

Within the study of identity, one of the first psychologists to write extensively on the subject was Erikson, ${ }^{5}$ who views identity as largely unconscious and believes that sense of self is constantly evolving both as an individual and as a member of society. Moreover, he emphasized that identity could not be isolated from culture, since it was an interconnected process, 'located' in the core of the individual and also in the core of his or her culture. ${ }^{5}$

Erikson's Theory has been widely used in developmental psychology. However, according to Hoare, ${ }^{6}$ although Erikson's theory is still influential, the contextual dimension in his construction of identity has been largely neglected, as it does not fit well with the field's preference for the positivist paradigm characterized by quantification, universalism, and statistical analysis. Accordingly, identity research in the field of social psychology has taken a different approach to group affiliation and social roles, being mainly dominated by two theories, the identity theory ${ }^{7,8}$ and the social identity theory, ${ }^{9,10}$ which have significant similiarites. ${ }^{11}$

The Identity Theory proposed by Stryker ${ }^{7}$ and Stryker and Staham ${ }^{8}$ attributes identity to a categorization of the self, in which the configuration of identity is related to the social roles played, i.e., the social role is the core of social identity, while self is made up of multiple identities. ${ }^{7}$ In this regard, the act of acquiring an identity requires other individuals to attribute the identity to the person, and the person himself/herself must accept and internalize this identity. From this perspective, identities are based on roles, self-concepts, and identifications of self with meanings and expectations related to the performance of a social role. ${ }^{11}$

In turn, the social identity theory ${ }^{9,10}$ similarly suggests that identities are different aspects of self-concept, and that social identity is the identification of the person with a particular social category or group, such as a sport. ${ }^{12}$ Thus, the formation of social identity occurs through self-categorization and social comparison processes. These categories usually precede the individual, and identities are largely related to positions within the social world. Investigations along these lines have focused on identities related to race, ethnicity, nationality and social class, ${ }^{13}$ with the assumption that each person's self-concept is derived from a unique combination of identities.

From this perspective, it is evident that in the realm of sports, research on identity emerged in the 1990s. Brewer et al. ${ }^{14}$ were the first researchers to conceptualize and systematically structure sport-related identity based on Stryker's proposals that the self is made up of multiple identities, and that identities are associated with the social roles played by the individual. Following this line of reasoning, Brewer et al. ${ }^{14}$ defined the degree of an individual's identification with the role of athlete, as Athletic Identity (Al).

Therefore, Al should be understood as an aspect of self-concept, more specifically as a cognitive framework that guides and organizes the processing of self-related information, ${ }^{14}$ as well as a social role which implies that identification is predominantly derived from feedback from others (e.g., parents, coaches, teammates, etc.). In addition, it should be emphasized that Brewer et al. ${ }^{14}$ developed a psychometric instrument for empirical research known as the Athletic Identity Measurement Scale (AIMS) in order to measure the athlete's degree of identification with his or her role. This first instrument consisted of 10 items, which were answered on a scale ranging from 1 to 7 , where 1 is I strongly disagree, and 7 I strongly agree, in which the higher the individual's score the higher the degree of AI. In this first version of the AIMS, the scale was conceptualized as one-dimensional. However, subsequent studies that verified AIMS dimensionality found three Al factors that were designated Social Identity (strength of identification with the role of athlete); negative affectivity (emotional responses to failure to fit the role of athlete); and exclusivity (lack of other social roles). ${ }^{15-17}$

Continually faced with these affirmations, different researchers sought to confirm Al as a latent trait for different populations, ${ }^{16-24}$ yet they emphasized inconsistencies regarding the confirmation of AIMS dimensionality. Accordingly, new items and new factorial structures were proposed for AIMS, ${ }^{25,26}$ while new measurement instruments were developed to measure $\mathrm{Al}^{27-29}$

It is known that the constructions, validations and adaptations of instruments are preponderant for the measurement of a construct to occur reliably, with the application of psychometric rigor deemed appropriate for this process, reducing the chances of errors and bias in the research. ${ }^{30,31}$ In this sense, the purpose of this particular integrative review was to verify studies that have developed or validated instruments to measure Al, and identify the psychometric properties presented by these instruments. Therefore, we aimed to: determine the theoretical frameworks of the instruments used to measure Al in the context of sports. We also aimed to verify how the psychometric rigor of the instruments used to measure the identity of the role of athlete was assessed, as well as which assessment instruments were used to measure the Al, which ones made it possible to effectively assess the intended construct, and which ones made it possible to distinguish the level, strength and generalization of Al.

\section{MATERIALS AND METHODS}

To achieve the objectives of this particular study, the authors used the integrative literature review based on Whittemore and Knaf, ${ }_{1}^{32}$ through the construction of analyses formed on a basis of six steps (Figure 1), in order to gain a better understanding of the subject matter based on previous studies. According to Mendes et al., "33 "the purpose of this method is to gather and systematize results of research on a delimited topic or issue in a systematic and orderly manner, helping develop and gain more knowledge about the subject matter."

This review found two types of epistemological scientific articles that support the concept and construct of Athlete Role Identity/Athletic Identity (Al), as well as studies that have proposed or empirically validated psychometric scales to measure Al.

We first consulted the terms ("athletic identity" OR "social identity" OR "self-identity"OR"athlete identity") AND ("athlete"OR "sport"OR"type of sport") AND ("validation" OR "validity" OR "adaptation") in the health descriptors (DECS), then performed the searches in the electronic databases Scopus, APA (PsycNET), Lilacs, Scielo, ScienceDirect, SPORTdiscus and Pubmed. The searches were carried out by three researchers, who undertook a rigorous search for the articles in the index bases, independently. Any queries that arose were analyzed in a consensus meeting between the researchers themselves.

As inclusion criteria it was established that: 1) the articles must have been published from 1990 to 2016; (2) published articles must evaluate Al; (3) articles must be original, not including review articles, books, dissertations, theses, notes, abstracts, or letters to the reader; (4) articles must use instruments to measure $\mathrm{Al}$; (5) articles must be published in indexed journals in databases used in English, Spanish or Portuguese.

Of the 1455 articles found, 21 met the inclusion criteria, considering the objectives of the study (Al measurement instruments), and the psychometric properties of the instruments. Figure 2 presents the step-by-step process followed for the selection of articles analyzed in this particular study. 


\section{- Choice and definition of the subject matter \\ - Objectives \\ - Identify keywords}

\section{Establishment of hypothesis or} research question
- Establishment of inclusion and exclusion criteria xclustio

- Use of database

- Selection of the studies

Sampling or literature search
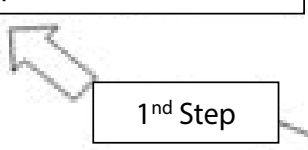

Synthesis of knowledge or submission of the review

- Summary of available evidence

- Creation of a document that describes the review in detail

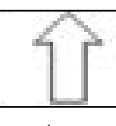

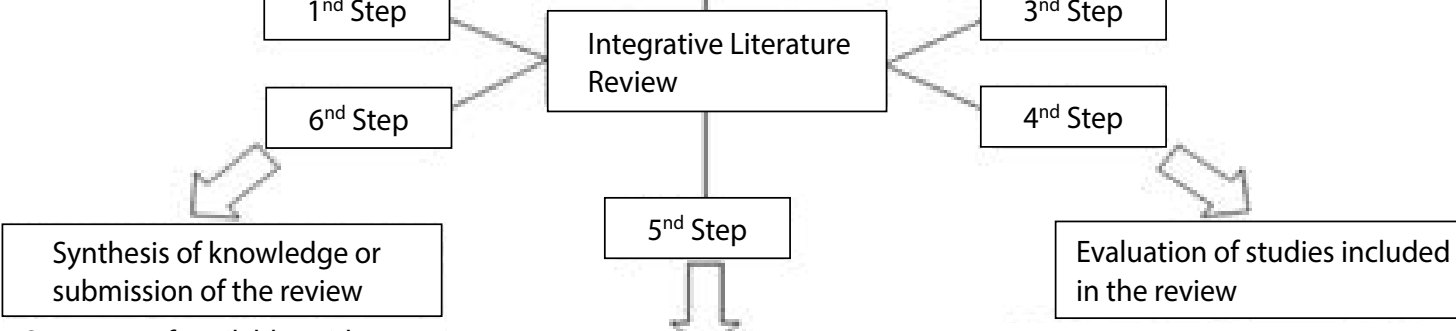

- Extraction of information

- Organize and summarize information

- Formation of the database

Categorization of the studies

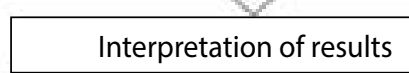

- Discussion of results

- Recommendation proposals

- Suggestions for future research projects
- Application of statistical analysis

- Inclusion/exclusion of the studies

- Critical analysis of the selected studies

Figure 1. Integrative review processes (Mendes et al. ${ }^{33}$ ).

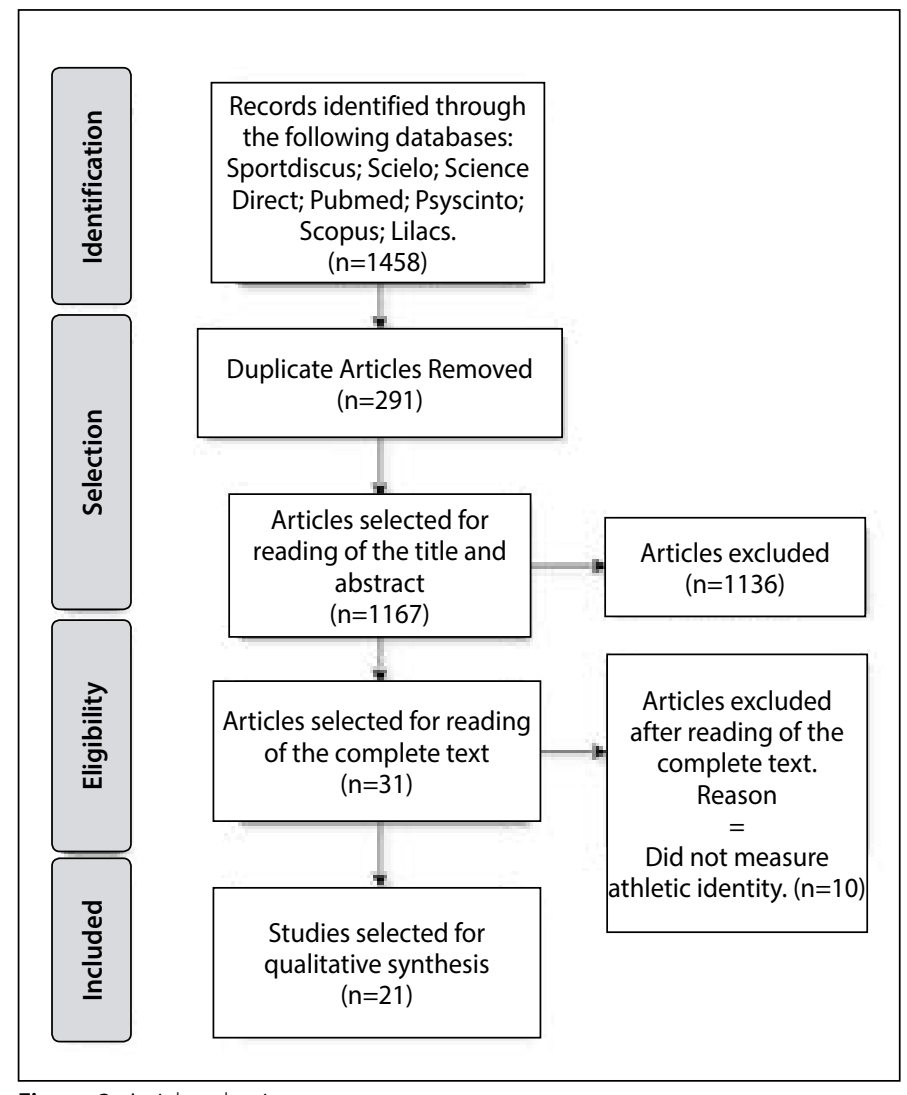

Figure 2. Article selection stages.

\section{RESULTS}

Table 1 presents a summary of the main information on the 21 articles covered in this integrative review: article title, first author, year of publication, population studied, objective of the study, Al measurement instruments, number of factors found, and psychometric properties. As regards Al measuring instruments, five self-report questionnaires for Al assessment were identified: Athletic Identity Measurement Scale (AIMS), Athletic Identity Measurement Scale-Plus (AIMS-Plus), Athletic Identity Questionnaire (AIQ), Academic and Athletic Identity Scale (AAIS), and Public-Private Athletic Identity Scale (PPAIS). There is also evidence that $57 \%$ articles presented the instrument used to assess Al in its entirety, while $43 \%$ only mentioned items belonging to it. Moreover, it was observed that $71 \%$ of the studies were based on the Al concept proposed by Brewer et al. ${ }^{14}$

We discovered 16 validations of the Athletic Identity Measurement Scale (AIMS) in its three versions (10-item AIMS; 7-item AIMS; AIMS Plus), for 11 different countries. This scale is the most frequently used Al measuring instrument in the world, according to this search. Regarding the 10-item AIMS version, eleven validations were found, while the version of the scale with seven items revealed the existence of five validation studies, and two studies performed validation for both versions. Regarding AIMS-Plus, we found two research projects that validated this version of the scale.

Regarding the dimensions of the Al measurement instruments, we identified twelve different factors of the construct among all the instruments incorporated in the study, and the dimensions that appear most often are: "social identity", "exclusivity" and "negative affectivity", referring to the 10-item AIMS, seven-item AIMS and AIMS-Plus scales.

In analyzing the psychometric properties of the instruments, we identified that the validation process stages were described in 52\% of the reviewed studies, all of which performed construct validity. However, only $4 \%$ had content validity, $28 \%$ criterion validity, $10 \%$ reliability, $10 \%$ convergent validity, $23 \%$ cross-cultural adaptation and $9 \%$ adaptation of a particular instrument item.

Regarding the statistical analyses used in the validation processes, we ascertained that 20 of the 21 studies included in the review made use of confirmatory factor analysis for construct validity, and eight conducted Cronbach's alpha test to measure the internal consistency of the 
Table 1. Characteristics of the articles included in the review.

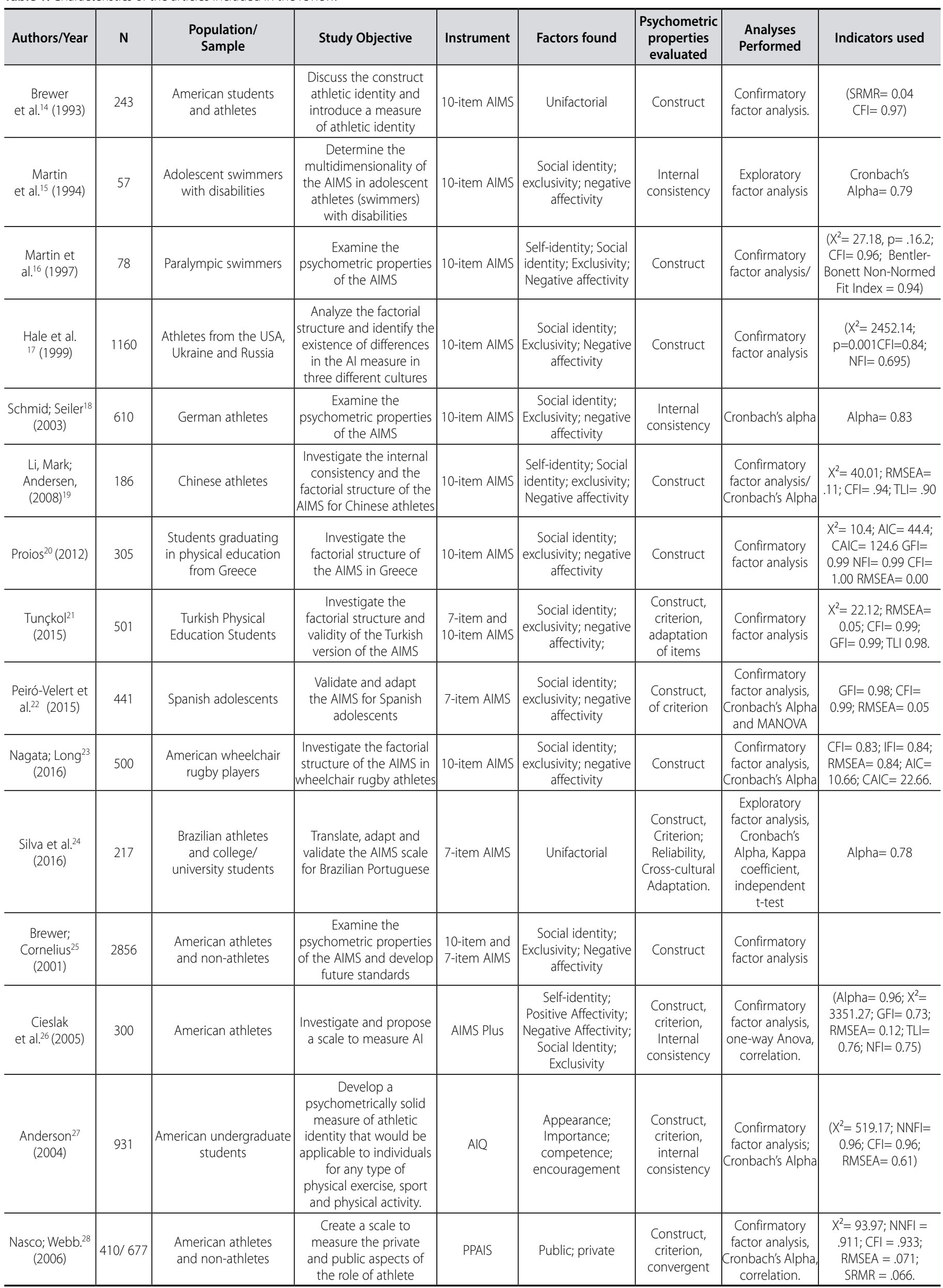




\begin{tabular}{|c|c|c|c|c|c|c|c|c|}
\hline Authors/Year & $\mathrm{N}$ & $\begin{array}{l}\text { Population/ } \\
\text { Sample }\end{array}$ & Study Objective & Instrument & Factors found & $\begin{array}{c}\text { Psychometric } \\
\text { properties } \\
\text { evaluated }\end{array}$ & $\begin{array}{l}\text { Analyses } \\
\text { Performed }\end{array}$ & Indicators used \\
\hline $\begin{array}{c}\text { Groff; Zabriskie, } \\
\text { (2006) }\end{array}$ & 33 & Para athlete skiers & $\begin{array}{l}\text { Determine the athletic } \\
\text { identity of elite skiers } \\
\text { with disabilities and } \\
\text { examine the factorial } \\
\text { structure of the AIMS }\end{array}$ & 10-item AIMS & $\begin{array}{c}\text { Social identity; } \\
\text { exclusivity; negative } \\
\text { affectivity }\end{array}$ & $\begin{array}{l}\text { Internal } \\
\text { consistency }\end{array}$ & Cronbach's Alpha & Alpha $=0.81$ \\
\hline $\begin{array}{l}\text { Visek et al. }{ }^{35} \\
\quad(2008)\end{array}$ & 699 & $\begin{array}{l}\text { American, British and } \\
\text { Chinese contact and } \\
\text { collision sport athletes. }\end{array}$ & $\begin{array}{c}\text { Test the psychometric } \\
\text { properties of the AIMS } \\
\text { in an American and } \\
\text { Chinese sample. }\end{array}$ & 7-item AIMS & $\begin{array}{c}\text { Social identity; } \\
\text { exclusivity; Negative } \\
\text { affectivity }\end{array}$ & $\begin{array}{l}\text { Construct } \\
\text { and Internal } \\
\text { consistency }\end{array}$ & $\begin{array}{c}\text { Confirmatory } \\
\text { factor analysis } \\
\text { and Pearson's } \\
\text { correlation }\end{array}$ & $\begin{array}{l}X^{2}(11)=32.61 \\
\text { SRMR }=.05, \text { CFI } \\
=.96, \text { RMSEA }= \\
.07 . \text { Alpha }=.76 .\end{array}$ \\
\hline $\begin{array}{l}\text { Anderson } \\
\text { et al. }{ }^{36}(2007)\end{array}$ & 408 & American adolescents & $\begin{array}{c}\text { Describe the } \\
\text { development of a } \\
\text { measure of the general } \\
\text { attribute of "athletic" in } \\
\text { adolescents, covering } \\
\text { exercise, sport, and } \\
\text { physical activity }\end{array}$ & 40-item AIQ & \begin{tabular}{|c|} 
Appearance; \\
competence; \\
importance of the \\
activity; engagement
\end{tabular} & Construct & $\begin{array}{l}\text { Confirmatory } \\
\text { factor analysis }\end{array}$ & $\begin{array}{c}\text { (RMSEA }=.055, \mathrm{NNFI} \\
\quad=.97, \mathrm{CFI}=.98)\end{array}$ \\
\hline $\begin{array}{l}\text { Anderson; } \\
\text { Colemanan }^{37} \\
\text { (2008) }\end{array}$ & 936 & $\begin{array}{l}\text { Children of different } \\
\text { ethnicities and } \\
\text { Hispanic children }\end{array}$ & \begin{tabular}{|c|} 
Adapt the AIQ \\
questionnaire \\
(adolescents) for children \\
and test its validity \\
\end{tabular} & AIQ Children & $\begin{array}{c}\text { Appearance; } \\
\text { competence; } \\
\text { importance of the } \\
\text { activity; competence }\end{array}$ & Construct & $\begin{array}{l}\text { Confirmatory } \\
\text { factor analysis }\end{array}$ & $\begin{array}{c}\text { RMSEA }=.061 \\
N N F I=.96 \\
C F I=.96)\end{array}$ \\
\hline $\begin{array}{c}\text { Cabrita } \\
\text { et al., }{ }^{38}(2014)\end{array}$ & 650 & Portuguese athletes & $\begin{array}{l}\text { Adapt and validate } \\
\text { the AIMS Plus for the } \\
\text { Portuguese population }\end{array}$ & AIMS Plus & \begin{tabular}{|c|} 
Self-identity; Positive \\
Affectivity; Negative \\
Affectivity; Social \\
identity; Exclusivity
\end{tabular} & \begin{tabular}{|c|} 
Convergent \\
construct \\
Cross-cultural \\
Adaptation \\
\end{tabular} & $\begin{array}{l}\text { Confirmatory } \\
\text { factor analysis }\end{array}$ & $\begin{array}{c}X^{2}=8.769 ; C F I=.895 ; \\
P C F I=.733 ; G F I= \\
.892 ; P G F I=.640 ; \\
\text { RMSEA }=.109 .\end{array}$ \\
\hline
\end{tabular}

Presented instrument in full; ${ }^{2}$ only mentioned items of the instrument; *Presented broad concept of Brewer's athletic identity; **Presented identity concept based on some other theory; ${ }^{\circ}$ Identified stages of the validation proces

evaluated instrument. For the criterion validity and discriminant validity analyses, three studies performed some kind of comparison test (ANOVA, MANOVA and independent t-test), while a further three conducted some form of correlation test (Spearman and Pearson).

\section{DISCUSSION}

This study examined the theoretical frameworks used in the 21 articles found on validation of athlete role identity instruments. At first we investigated whether the theoretical assumptions of Athlete Role Identity/Athletic Identity (AI) were easily identified. In this context, we identified 17 articles that were essentially based on the conceptualization of Al of Brewer et al. ${ }^{14}$ and a further four studies based on different theories, such as the structural identity theory ${ }^{7}$ and the cognitive theory of identity. ${ }^{39}$

In studies with unclear theoretical perspectives, several authors were cited in the discussion of identity, 5,14,40 but the differences and contradictions in these approaches were not pointed out. This lack of coherence in the theoretical perspectives presented made it difficult to understand how the authors worked with the concept. In such cases, it appeared that identity was taken as a word of common sense, not providing a theoretical basis and a declared position of the instrument's proponents on this concept. In this regard, the review reveals that Sport Psychology has engaged relatively little with psychological identity theories (Erikson's theory of development, the identity theory, and the social identity theory). Instead, the specific conceptualization of sport proposed by Brewer et al..$^{14}$ dominated research in this area.

Regarding the Al measurement instruments, of the twenty-one articles included in the study, we must emphasize that five Al assessment self-report questionnaires were identified: AIMS, AIMS-Plus, AIQ, AAIS and PPAIS. AIMS emerged as the oldest questionnaire involving the highest number of validation studies and psychometric characteristics ${ }^{14}$ investigated in the context of sports, with these extending both to populations of different cultures and languages, 17,21,22,24,39-43 and to special populations (individuals with special needs). ${ }^{16,35}$ AIMS initially emerges as a one-dimensional measure of athletic identity with 10 items..$^{14}$ However, after several assignments with studies confirming its factorial structure, it took on a multidimensional structure with three factors: social identity, exclusivity and negative affectivity. ${ }^{77}$ Based on the study by Brewer and Cornelius, ${ }^{25}$ we noticed a reference to a reduced version of seven items. The outcome of the psychometric assessments reveals some inconsistencies in its factorial structure. For example, Li and Anderson ${ }^{18}$ report AIMS with a poor factorial structure and with four factors, a result that differs from others establishing AIMS with three factors. ${ }^{17}$ This questionnaire is used as a starting point to develop another two, AIMS-Plus and PPAIS, which seek to fill in the gaps left by AIMS. While AIMS-Plus adds two dimensions to Al: self-identity and positive affectivity, ${ }^{26}$ PPAIS restructures the Al model into two large dimensions: public dimension and private dimension. ${ }^{43}$

The idea that $\mathrm{Al}$ is one of the facets of the individual's self prompted the development of another measure that extends to the context of exercise and physical activity, known as AIQ, which consists of four factors: appearance, competence, importance of physical activity/sport/exercise and reinforcement of others. ${ }^{27}$ For this measure there are validations for different audiences such as children, adolescents and adults. $.27,28,36,37$

The robustness of these measures and the assurances of validity still remain open, considering the variability of populations and context, particularly those of an intercultural nature. Regarding the dimensions of $\mathrm{Al}$, it is possible to observe that the first studies on the topic found three dimensions for the construct: social identity, exclusivity and negative affectivity. ${ }^{15-17,25}$ Other subsequent studies found the presence of one more factor, self-identity, which is related to the athlete's degree of personal awareness of his or her role in the context of sports, i.e., how the individual sees himself or herself in the role of athlete. ${ }^{26}$ It should be noted that this dimension was not considered in the first studies of Al and positive affectivity, which was also considered an important dimension of $\mathrm{Al}$ after the studies by Cielask, Fink and Pastore. ${ }^{26}$

The dimensions appearance, competence, importance of activity and engagement, proposed byAnderson, ${ }_{1}{ }^{27}$ are based on the identity assumptions of Stryker and Serpe ${ }^{44}$ and Stryker e Statham, ${ }^{8}$ who point out that people organize their multiple identities into a"prominence" or hierarchy of salience, considering that the more important a particular identity is, the more time and effort the individual will invest to ensure 
its dissemination. On the other hand, Nasco's ${ }^{28}$ proposal of a public and private dimension of $\mathrm{Al}$ is based on the identity assumptions of Burke, ${ }^{34}$ presenting identity as a set of meanings applied to the self in a social situation or role.

A certain psychometric rigor can be seen in the instruments used to measure $\mathrm{Al}$ in the studies present in this integrative review, mainly explained by the construct validity. This was the most common psychometric property in the reviewed studies. Criterion validity (concurrent and predictive validity) was found in only $28 \%$ of the reviewed studies. This type of validity allows us to assess the effectiveness of a test in predicting a certain performance of a future action, confirming whether a test is empirically associated with external criteria related to the measurement of other instruments already validated for the same construct. ${ }^{45}$ From this perspective, Feltz et al. ${ }^{46}$ suggest that researchers should remain vigilant to ensure that the measure is consistent and constructed for specific domains so as to avoid decontextualized issues.

Regarding reliability, eight studies conducted Cronbach's alpha test to verify the internal consistency of the instrument being investigated. We should emphasize that reliability in psychometrics is one of the procedures carried out to verify hypotheses, dealing with the consistency and accuracy of a test, i.e., it is a term that suggests infallibility, despite the fact that test scores are always subject to a measurement error.

There are a number of factors that can interfere with test scores due to the higher propensity for error in social and behavioral sciences, such as "the tester, the examiner, and the context in which the testing takes place".47 Reliability is also characterized in view of the test scores and not the test itself; it is not absolute and unchangeable, taking into account the measurement error and the degree of influence of this very error on the result. ${ }^{47}$

The true score does not exist in reality, but would mean the hypotheses free from any error. Accordingly, the true score would be the "average score in a hypothetical distribution that would be obtained if the subject underwent the same test an infinite number of times"47 Each type of test has to have a different way of estimating the error, requiring a different way of measuring it. Finally, it should be noted that reliability, along with other variables, has a direct and indispensable relationship with validity. ${ }^{47}$

Regarding the analyses used in the studies present in this review, it was ascertained that seventeen studies performed a confirmatory factor analysis. This type of analysis concerns the verification of the hypothesis of legitimacy of the representation of constructs, which seeks to identify, in the empirical data, the constructs previously operationalized in the instrument. ${ }^{48}$ This analysis is part of the Classical Test Theory (CTT). However, according to Pasquali, ${ }^{31}$ factor analysis makes some strong postulations that are not always consistent with the reality of the facts. For example, factor analysis assumes that subject responses to instrument items are determined by a linear relationship between them and the latent traits. ${ }^{31}$ An alternative used in psychometrics to make up for CTT shortcomings is the Item Response Theory (IRT). This theory has clear advantages in its application, particularly the possibility of discovering the contribution of each item to the final result and the comparison of tests composed of different items. ${ }^{48}$ It should be noted that the IRT was not used in any of the studies included in this particular review.

\section{CONCLUSION}

The main objective of this review was to verify studies that developed or validated instruments to measure athlete role identity, identifying the psychometric properties that these instruments presented. We were able to discover that different instruments were used in studies with the same objectives: the measurement of Al. It was also possible to notice that the researchers' concern with validating instruments using psychometric criteria dates back to the 1990s. We found that most of the studies were based on the Al assumptions of Brewer, Van Raalte \& Linder (1993).

Regarding the validity process, we ascertained that all the studies included in the review performed construct validity. However, none conducted the IRT for this process. It is also important to note that few studies performed criterion validity, an important stage in psychometric processes.

Therefore, we suggest that the IRT be applied for future studies in the validation process of instruments related to athlete role identity, in order to make the construct validation process more reliable, giving greater importance to the items included in the instrument. We also recommend that the criterion validity process be performed in order to verify the stability of the construct in new populations.

A limitation of this study is the non-analysis of methodological quality of the studies included in the review. However, it is very difficult to find scales that measure methodological quality for psychometric studies.

All authors declare no potential conflict of interest related to this article

AUTHORS' CONTRIBUTIONS: Each author made significant individual contributions to this manuscript. WRS (0000-0003-0568-4272)* and TL (0000-0002-2303-2297)*: were the main contributors in the writing of the manuscript; AF (0000-0001-8972-6075)*, GFM (0000-0003-3551-5963)* and FLC (0000-0002-3074-0988)*: conducted the literature search, reviewed the manuscript, and contributed to the intellectual concept of the study. ${ }^{*}$ ORCID (Open Researcher and Contributor ID).

\section{REFERENCES}

1. Ronkainen NJ, Kavoura A, Ryba TV. A meta-study of athletic identity research in sport psychology: Current status and future directions. Inter Review Sport Exerc Psychol. 2016;9(1):45-64.

2. James W. The principles of psychology. v. 1, New York: Holt. 1890.

3. Jussim L, Ashmore RD. Fundamental issues in the study of self and identity: contrasts, contexts, and conflicts. In: Jussim L, Ashmore RD (Eds.), Self and identity: fundamental issues. New York: Oxford University Press, 1997. p. 218-30.

4. Côté JE, Levine CG. Identity, formation, agency, and culture: a social psychological synthesis. New York: Lawrence Erlbaum Associates. 2002.

5. Erikson EH. Identity: Youth and crisis. New York: WW Norton \& Company. 1968.

6. Hoare CJ. Three missing dimensions in contemporary studies of identity: the unconscious, negative tributes, and society. J Theor Philos Psychol. 2013;33(1):51-67.

7. Stryker S. Symbolic interactionism: A social structural version. Menlo Park, CA: Benjamin-Cummings. 1980.

8. Stryker S, Statham A. Symbolic interaction and role theory. 1985.

9. Tajfel H. Some developments in European social psychology. Eur J Social Psychol. 1972;2(3)307-21.

10. Tajfel H. Human groups and social categories: studies in social psychology. London: Cambridge University Press, 1981

11. Stets JE, Burke PJ. Identity theory and social identity theory. Social Psychol Quart. 2000;63(3):224-37.
12. Fink JS, Parker HM, Brett M, Higgins J. Off-field behavior of athletes and team identification: Using socia identity theory and balance theory to explain fan reactions. J Sport Manag. 2009;23:142-55.

13. Thoits PA, Virshup LK. Me'sandwe's. In: Jussim L, Ashmore RD (Eds.), Self and identity: fundamental issues. New York: Oxford University Press, 1997. p. 106-36.

14. Brewer BW, Van Raalte JL, Linder DE. Athletic identity: Hercules' muscles or Achilles heel? Inter J Sport Psychol. 1993;24:237-54

15. Martin JJ, Mushett CA, Eklund R. Factor structure of the Athletic Identity Measurement Scale with adolescent swimmers with disabilities. Inter J Adapted Phys Educ Res. 1994;1(1):87-100.

16. Martin JJ, Eklund RC, Mushett CA. Factor structure of the athletic identity measurement scale with athletes with disabilities. Adapted Phys Activity Quart. 1997;14(1):74-82.

17. Hale BD, James B, Stambulova N. Determining the dimensionality of athletic identity: a "Herculean" cross-cultural undertaking. Inter J Sport Psychol. 1999;30(1):83-100.

18. Schmid J, Seiler R. Identity in high-performance sport: psychometric investigations with a German Language adaptation of the Athletic Identity Measurement Scale (AIMS-D). Diagnostica. 2003;49(4):176-83.

19. Li HY, Andersen MB. Athletic identity in China: examining the AIMS in a Hong Kong sample. Inter J Sport Exerc Psychol. 2008;6(2):176-88 
20. Proios M. Factor validity of the Athletic Identity Measurement Scale in a Greek sample. Inter J Sport Exerc Psychol. 2012;10(4):305-13.

21. Tunçkol HM. Applying athletic identity measurement scale on physical Educators: Turkish version of AIMS. Educ Res Reviews. 2015;10(2):177-83.

22. Peiró-Velert C, Valencia-Peris A, Fos-Ros V, Devís-Devís J. Identidad deportiva en adolescentes españoles: propiedades psicométricas de La versión em español de la escala Athletic Identity Measurement Scale-E. Rev Latinoamericana Psicol. 2016;48(1):8-17.

23. Nagata S, Long T. Examining validity of the athletic identity measurement scale in a sample of wheelchair rugby athletes. Inter J Sport Psychol. 2016;47(3):282-95.

24. Silva WR, Ferrari EP, Medeiros TE, Freitas KT, Tkac CM, Cardoso FL. Athletic identity measurement scale: translation, adaptation and validation for Brazil. Motriz: Rev Educ Fis. 2016;22(1):42-7.

25. Brewer BW, Cornelius AE. Norms and factorial invariance of the Athletic Identity Measurement Scale. Acad Athletic Journal. 2001;15(2):103-13.

26. CieslakTJ, Fink JS, Pastore DL. Measuring the athletic identity construct: Scale development and validation. J Sport Exerc Psychol. 2005;27(Suppl):S48.

27. Anderson CB. Athletic identity and its relation to exercise behavior: Scale development and initial validation. J Sport Exerc Psychol. 2004;26(1):39-56.

28. Nasco SA, Webb WM. Toward an expanded measure of athletic identity: The inclusion of public and private dimensions. J Sport Exerc Psychol. 2006;28(4):434-53.

29. 2 Yukhymenko-Lescroart, MA. Students and athletes? Development of the Academic and Athletic Identity Scale (AAIS). Sport Exerc Perf Psychol. 2014;3(2):89-94.

30. Barroso ML. Validação do participation motivation questionnaire adaptado para determinar motivos de prática esportiva de adultos jovens brasileiros, 2007. 129 f. [Dissertação de Mestrado em Ciências do Movimento Humano]-Universidade do Estado de Santa Catarina (UDESC), Florianópolis, 2007.

31. Pasquali L. Psicometria: teoria dos testes na psicologia e na educação. Vozes, 2009

32. Whittemore R, Knafl K. The integrative review: updated methodology. J Adv Nurs. 2005;52(5):546-53.

33. Mendes KD, Silveira RC, Galvão CM. Revisão integrativa: método de pesquisa para a incorporação de evidências na saúde e na enfermagem. Texto Contexto Enferm. 2008;17(4):758-64.

34. Groff DG, Zabriskie RB. An exploratory study of athletic identity among elite alpine skiers with physical disabilities: Issues of measurement and design. J Sport Behav. 2006;29(2):126-41.

35. Visek AJ, Hurst JR, Maxwell JP, Watson JC. A cross-cultural psychometric evaluation of the athletic identity measurement scale. J Appl Sport Psychol. 2008;20(4):473-80.

36. Anderson CB, Coleman KJ. Adaptation and validation of the athletic identity questionnaire-adolescent for use with children. J Physl Act Health. 2008;5(4):539-58.

37. Anderson CB, Mâsse LC, Hergenroeder AC. Factorial and construct validity of the athletic identity questionnaire for adolescents. Med Sci Sports Exerc. 2007;39(1):59-69.

38. Cabrita TM, Rosado AB, Leite TO, Sousa PM. Adaptation of the athletic identity measurement scale (AIMS-Plus) for the Portuguese population. Psicol Reflex Crit. 2014;27(1): 29-37.

39. Holland JL. Making vocational choices: A theory of vocational personalities and work environments. $3^{\text {rd }}$ ed. Odessa, FL, US: Psychol Asses Res. 1997

40. Burke PJ. Identity processes and social stress. Am Sociol Review. 1991;56:836-49.

41. Hsieh JF. National identity and Taiwan's Mainland China policy. J Contemp China. 2004;13(40):479-90.

42. Tasiemski T, Kennedy P, Gardner BP, Blaikley RA. Athletic identity and sports participation in people with spinal cord injury. Adapt Phys Act Q. 2004;21(4):364-78.

43. Nasco SA, Webb WM. Toward an expanded measure of athletic identity: The inclusion of public and private dimensions. J Sport Exerc Psychol 2006;28(4):434-53.

44. Stryker S, Serpe RT. Commitment, identity salience, and role behavior: Theory and research example. In: Ickes W, Knowles ES (eds). Personality Roles Social Behavior. New York: Springer-Verlag, 1982. p. 119-218.

45. Pasquali L. Instrumentação psicológica: fundamentos e prática. Porto Alegre: Artmed, 2010.

46. Feltz S, Short E, Sullivan J. Self-efficacy in sport. Human Kinetics, 2008.

47. Urbina S. Fundamentos da testagem psicológica. Artmed Editora, 2007.

48. Embretson SE, Reise SP. Item response theory for psychologists. Lawrence Earlbaum Associates, Mahwah, NJ. 2000. 